\title{
THE EFFECT OF DIESEL PROPERTIES ON THE EMISSIONS OF PARTICULATE MATTER
}

\author{
A. BELLO*, J. TORRES, J. HERRERA, J. SARMIENTO \\ Ecopetrol - Instituto Colombiano del Petróleo, A.A. 4185 Bucaramanga, Santander, Colombia \\ E-mail: abello@ecopetrol.com.co
}

\begin{abstract}
A evaluation was carried out on the effect that modifying some properties of Colombian diesel fuel, such as final boiling point (FBP), density and sulfur content, has on the emissions of particulate matter (PM). Four diesel engines with different technologies and work capacity were used for the evaluation. Different alternatives to modify the properties of commercial diesel fuel, from the fuel treatment viewpoint, as well as that of the incorporation or segregation of some of the streams from the pool at the Barrancabermeja Refinery were studied. The particulate matter was measured using a partial flow (AVL-SPC472) Constant Volume Sampler (CVS) with following the 13-step steady state European cycle and the ECE-R49 European guideline. The tests were performed at the Instituto Colombiano del Petróleo - (ICP) test cell in the city of Bucaramanga, Colombia. General tendencies show reductions of up to $25 \%$ in PM emissions when final boiling point and sulfur content are reduced. But levels of reduction vary from one engine to another depending on technology and working time. As a baseline, the emission levels of the commercial diesel fuel for each engine are used, and as a reference the results obtained are compared with the EURO I and II European standards defined for the emission levels of heavy duty engines.
\end{abstract}

Se evaluó el efecto que tiene el modificar algunas de las propiedades del combustible diesel colombiano, como el punto final de ebullición (PFE), la densidad y el contenido de azufre, sobre las emisiones de material particulado (MP). Para la evaluación se utilizaron cuatro motores diesel de diferentes tecnologías y niveles de trabajo. Se estudiaron diferentes alternativas para modificar las propiedades del diesel comercial, tanto desde el punto de vista de tratamiento del combustible, como de la incorporación o segregación de algunas corrientes del pool de la Refinería de Barrancabermeja. Las mediciones de material particulado se realizaron utilizando un equipo de Muestreo a Volumen Constante (Constant Volumen Sampler, CVS) de flujo parcial (AVL-SPC472), siguiendo el ciclo europeo de 13 pasos de estado estable y la directiva europea ECE-R49. Las pruebas fueron realizadas en el banco de potencia del Instituto Colombiano del Petróleo - ICP, en la ciudad de Bucaramanga, Colombia. Las tendencias generales muestran reducciones hasta de un $25 \%$ en las emisiones de material particulado al reducir el punto final de ebullición y el contenido de azufre, pero los niveles de reducción varían de un motor a otro dependiendo de su tecnología y tiempo de uso. Como línea base se utiliza los niveles de emisiones del diesel comercial para cada motor y a manera de referencia, los resultados obtenidos se comparan con los estándares europeos EURO I y II, definidos para los niveles de emisiones de motores de trabajo pesado.

Keywords: Diesel, Particulate Matter, Final Boiling Point, Sulfur Content.

\footnotetext{
* Corresponding author
} 


\section{INTRODUCTION}

The presence of particulate matter in diesel vehicle exhaust fumes is the result of incomplete fuel combustion. This particulate matter consists mainly of porous coal no greater than several micras in size. Around and within these nuclei are condensed and absorbed hydrocarbons, sulfates (mainly sulfuric acid, coming from the sulfur in the fuel) and along with them, water. In addition, traces of some other elements can also be found (Owen and Coley 1990).

The black smoke, which is the visible way to detect $\mathrm{PM}$ emissions, is produced when engines work under heavy load conditions, due to the fact that the air: fuel ratio becomes very rich. Mechanical factors can influence this phenomenon, such as overloading the equipment or excess fuel feed, due to poor pump calibration or deficient injector maintenance. Nevertheless, fuel quality also affects the emission of black smoke, even when the engine is well maintained and controlled. Table 1 summarizes the effect of physical-chemical properties of diesel fuel on the combustion process. Nevertheless, the response to changes in fuel properties can be affected by engine design as well as fuel properties. That is, engine design affects the relationship between fuel properties and emissions (Asaumi 1992).

It has been found that the basic parameters that contribute to PM emissions are fuel sulfur content and distillation curve. The reduction of sulfur content in fuel generates a reduction in the levels of particle emissions and there is a direct relation between the fuel's FBP and the level of PM emissions (Opris 1993). Nevertheless, the introduction of low sulfur diesel fuels in some parts of the world has coincided with an increase in the report of faulty pumps due to excessive levels of wear from friction. Therefore, the studies of sulfur reduction should be carried out along with studies on fuel lubricant properties (Lubricity).

Other parameters of fuel quality that influence PM emissions or black smoke are cetane number, density and aromatic content, which is not normally specified. Nevertheless, the interrelation that exists between many fuel characteristics makes it difficult to identify the contribution of any individual property. For example, although the gas oil that comes from catalytic cracking has a higher aromatic content than the direct atmospheric distillates, its density is higher and it has lower cetane numbers, which brings a joint effect that tends to increase the emission of black smoke, but has been difficult to quantify individually (Asaumi 1992). There is also an interrelation between FBP, density and sulfur content because of their tendency to concentrate more in heavy fractions, which has made it very difficult to evaluate the individual influence of each on PM emissions.

Due to the impulse in the use of diesel engines on mass transport vehicles during the last year in different cities in Colombia, it is necessary to seek the best options to reduce emissions to a minimum. The objective of this study is to evaluate some of the technical alternatives of the Barrancabermeja Refinery to improve the

Table 1. Characteristics of diesel fuel and their influence on combustion

\begin{tabular}{|l|l|}
\hline \multicolumn{1}{|c|}{ PROPERTY } & \multicolumn{1}{c|}{ PARAMETERS AFFECTED } \\
\hline CETANE NUMBER & Power, consumption, cold/hot ignition, emissions, noise, engine life. \\
\hline SULFUR CONTENT & Particles, lubricant degradation, engine life. \\
\hline DISTILLATION & Particles, black smoke, white smoke, HC, NOx \\
\hline DENSITY & Power, consumption, black smoke, engine life. \\
\hline AROMATIC CONTENT & Cold ignition, black smoke, emissions, noise, engine life. \\
\hline VISCOSITY & Power, consumption, cold/hot ignition, black smoke, particles, wear of injectors and injection pump. \\
\hline STABILITY & Formation of deposits, plugging of filters, emissions. \\
\hline COLD FLOW & Wax in the tank, filtration, cold operation, deposition of waxes. \\
\hline WATER AND SEDIMENTS & Corrosion, wear of injectors, deposits in the tank, plugging of filters. \\
\hline
\end{tabular}


quality of the diesel fuel sold in the central region of the country to reduce the emission of particulate matter generated by the vehicles.

\section{METHOD}

Due to the great number of variables handled in this kind of test, the interrelation between the different physical-chemical properties of the fuel, and the simultaneous unavailability of fuels and engines, the testing program was designed so that the greatest number of fuels could be evaluated in each engine. The results obtained are evaluated for each and every engine and this determines the general trends in the reduction of PM emissions from modifying the properties of the commercial diesel fuel.

In order to evaluate the emissions of particulate matter, the 13-step steady state European cycle was used, developed in an AVL-SPC472 dilution microtunnel that works under the operation principle of a partial flow CVS. In accordance with the ISO 8178-1 standard, the maximum repeatability threshold for this procedure of emission evaluation is $\pm 5 \%$. According to the experimental results obtained, before beginning evaluation testing, it was found that under the work conditions at the ICP test cell with the AVL-SPC472, the repeatability threshold for two consecutive tests can be in the range of $\pm 3 \%$. For any case outside this range, a third test of verification should be performed.

\section{Obtaining test fuels}

Due to the fact that it was not possible to have all of the fuel streams simultaneously with the four engines used, tests were performed for each engine with a different set of fuels. Nevertheless, the baseline of emissions for the four engines was carried out with commercial fuel within the current quality specifications.

\section{Variation in final boiling point}

Using a commercial diesel fuel, samples of 593, 613 and $633 \mathrm{~K}\left(320,340,360^{\circ} \mathrm{C}\right)$, True Boiling Point (TBP) of FBP were obtained by fractionation in the distillation units of the crude-oil laboratory. The fractionation was done in a Fischer AUTODEST 800 distillation unit following the guidelines of the ASTM D-2892 standard.
The cuts were characterized by their physical-chemical properties.

\section{Variation in density}

Samples were prepared with the same densities as the cuts obtained by fractionation 593, 613 and $633 \mathrm{~K}$ $\left(320,340,360^{\circ} \mathrm{C}\right)$, by mixing the original commercial diesel fuel with kerosene. This is how fuel with the same density as the cuts obtained by distillation, but with Final Boiling Points equal to that of the commercial fuel, were obtained.

\section{Variation in sulfur content}

In order to obtain fuels with lower sulfur levels than those of the commercial fuel, two alternatives were used; pilot plant hydrotreatment of two samples of commercial diesel fuel, and the low sulfur content diesel fuel (1000 ppm, $600 \mathrm{ppm}$ ) from the Barrancabermeja Refinery obtained by processing crude oils with special characteristics in the U-150 and U-2000 atmospheric distillation units. Nevertheless, the operational adjustments also modify other properties in the fuel, which influence emissions.

As illustrated in Table 2, differences among the fuels obtained at the refinery, besides sulfur content, also occur in variables such as density, distillation curve, cetane index, viscosity, etc. Therefore, the effect of reduction in PM emissions is not strictly due to the reduction in fuel sulfur content, but a combination of variables. Nevertheless, since the basic objective of these operational modifications was to reduce sulfur content and that this, in the short term, is the most feasible technical option to improve commercial fuel quality and reduce PM emissions, the analyses will be carried out as if the variation in emissions were due to the effect of sulfur reduction.

The fuel samples obtained at the Barrancamermeja Refinery were: Diesel from the U-150 (920 ppm sulfur) by processing a blend of Cupiagua $(60 \%)$ and Zulia + Caño Limón ( $40 \%$ ) crude oils, diesel from the U-2000 (600 ppm) by processing Cusiana crude oil and a blend of the other streams from the pool with a sulfur content of $3400 \mathrm{ppm}$ (Mez GCB). Since the objective was to obtain samples with sulfur content of $600 \mathrm{ppm}$ and $1000 \mathrm{ppm}$, blends were prepared at the laboratory using Mez GCB diesel fuel and the cut from the U-2000. The second was obtained by mixing diesel fuel from the U150 with the Mez GCB. In addition, diesel fuel with 
Table 2. Characterization of the Refinery diesel fuel. Engine 2.

\begin{tabular}{|c|c|c|c|c|c|}
\hline TEST & Mez GCB & $\begin{array}{l}\text { U-2000+ } \\
\text { Mez GCB }\end{array}$ & $\begin{array}{l}\text { U-150+ } \\
\text { Mez GCB }\end{array}$ & $\begin{array}{c}\text { HDT } 2 \\
\text { Pilot PL. }\end{array}$ & U-2000 \\
\hline API Gravity & 29.3 & 34.2 & 37.1 & 33.3 & 35.1 \\
\hline Density at $288.6 \mathrm{~K}\left(\mathrm{Kg} / \mathrm{m}^{3}\right)$ & 879.5 & 853.5 & 838.8 & 858.2 & 848.9 \\
\hline Sulfur (\% w) & 0.34 & 0.105 & 0.101 & 0.051 & 0.061 \\
\hline Viscosity at $313 \mathrm{~K}\left(\mathrm{~m}^{2} / \mathrm{s}\right)$ & 5.17E-06 & 3.10E-06 & 2.99E-06 & 3.69E-06 & 2.89E-06 \\
\hline Flash Point ( K) & 361.0 & 362.0 & 362.0 & 350.0 & 363.0 \\
\hline Cetane Index & 44.8 & 49.0 & 55.4 & 47.9 & 48.9 \\
\hline Lubricity $(\mu \mathrm{m})$ (D-6079) & 225 & 248 & 306 & $494^{*}$ & 261 \\
\hline Distillation ( $K$ ) & D-86 & D-86 & D-86 & D-86 & D-86 \\
\hline $\mathrm{IBP}$ & 486.8 & 493.1 & 491.3 & 460.8 & 481.5 \\
\hline 5\% Evaporated & 519.3 & 512.1 & 513.5 & 492.1 & 507.4 \\
\hline 10\% Evaporated & 530.8 & 518.3 & 521.6 & 505.9 & 513.2 \\
\hline $20 \%$ Evaporated & 543.7 & 524.7 & 530.7 & 524.1 & 520.9 \\
\hline 30\% Evaporated & 554.1 & 532.0 & 536.7 & 537.6 & 527.2 \\
\hline 40\% Evaporated & 563.1 & 539.0 & 541.8 & 547.8 & 533.5 \\
\hline $50 \%$ Evaporated & 572.6 & 546.2 & 547.0 & 557.2 & 539.9 \\
\hline $60 \%$ Evaporated & 582.8 & 554.9 & 552.5 & 567.4 & 547.1 \\
\hline 70\% Evaporated & 594.5 & 564.7 & 559.1 & 579.0 & 556.0 \\
\hline 80\% Evaporated & 607.8 & 577.3 & 567.7 & 592.3 & 566.5 \\
\hline 90\% Evaporated & 625.7 & 593.5 & 580.6 & 611.2 & 580.1 \\
\hline 95\% Evaporated & 642.3 & 607.0 & 590.8 & 628.1 & 589.6 \\
\hline FBP & 661.3 & 627.5 & 613.4 & 652.2 & 598.5 \\
\hline Residue & 0.6 & 0.6 & 0.3 & 0.8 & 1.0 \\
\hline
\end{tabular}

* $260 \mu \mathrm{m}$ with additive. Max. threshold SAE specification, 450 um

300 and 500 ppm sulfur contents were obtained at the Pilot Plant by hydro-treating the commercial diesel fuel.

\section{CHARACTERISTICS OF THE FUELS EVALUATED}

Tables 2, 3, 4, 5, 6, 7 and 8 summarize the characteristics of the fuels tested in the different engines. The fuels in Table 2 include the determination of HFRR Lubricity (ASTM D6079), due to problems of accelerated wear detected worldwide when sulfur is reduced to $500 \mathrm{ppm}(0.05 \% \mathrm{wt})$.

\section{MEASURING EMISSIONS}

PM emissions were determined using a partial flow (AVL-SPC472 dilution micro-tunnel) (CVS). The 13step steady state cycle was followed along with the guidelines established in the ECE R-49 European standard. This is the procedure specified to evaluate the level of emissions from heavy-duty internal combustion engines according to the Euro I and Euro II standards. The tests were performed in the ICP test cell using the engines indicated in Table 9. 
Table 3. Characterization of the disel fuel and its fractions. Engine 2.

\begin{tabular}{|c|c|c|c|c|}
\hline TEST & $\begin{array}{c}\text { Commercial } \\
\text { Diesel }\end{array}$ & $\begin{array}{c}\text { FBP - } 593 \mathrm{~K} \\
\text { Diesel }\end{array}$ & $\begin{array}{c}\text { FBP }-613 \mathrm{~K} \\
\text { Diesel }\end{array}$ & $\begin{array}{c}\text { FBP }-633 \mathrm{~K} \\
\text { Diesel }\end{array}$ \\
\hline AP| Gravity & 31.7 & 33.9 & 33.1 & 32.4 \\
\hline Density at $288.6 \mathrm{~K}\left(\mathrm{Kg} / \mathrm{m}^{3}\right)$ & 866.6 & 855.1 & 859.2 & 862.9 \\
\hline Sulfur $(\% w)$ & 0.292 & 0.177 & 0.213 & 0.239 \\
\hline Viscosity at $313 \mathrm{~K}\left(\mathrm{~m}^{2} / \mathrm{s}\right)$ & $4.14 \mathrm{E}-06$ & $2.78 \mathrm{E}-06$ & $3.17 \mathrm{E}-06$ & $3.49 \mathrm{E}-06$ \\
\hline Flash Point ( $K$ ) & 347 & 346 & 346 & 350 \\
\hline Cetane Index & 46.4 & 44.6 & 44.9 & 45.3 \\
\hline Yield \% w (D-2892)* & - & 68.0 & 81.0 & 88.0 \\
\hline Distillation (K) & D-86 & D-86 & D-86 & D-86 \\
\hline IBP & 462.5 & 470.6 & 445.4 & 458.2 \\
\hline 5\% Evaporated & 496.6 & 487.7 & 487.5 & 494.7 \\
\hline 10\% Evaporated & 512.0 & 499.9 & 500.6 & 508.1 \\
\hline $20 \%$ Evaporated & 531.8 & 514.8 & 520.1 & 524.6 \\
\hline $30 \%$ Evaporated & 544.1 & 527.6 & 534.2 & 537.3 \\
\hline 40\% Evaporated & 554.4 & 535.3 & 542.8 & 546.6 \\
\hline $50 \%$ Evaporated & 563.9 & 541.8 & 550.1 & 554.9 \\
\hline $60 \%$ Evaporated & 574.3 & 547.9 & 557.4 & 562.9 \\
\hline 70\% Evaporated & 585.9 & 554.0 & 565.2 & 571.5 \\
\hline $80 \%$ Evaporated & 599.9 & 560.8 & 573.8 & 581.6 \\
\hline $90 \%$ Evaporated & 619.5 & 569.9 & 584.8 & 593.7 \\
\hline 95\% Evaporated & 637.3 & 576.8 & 593.1 & 602.4 \\
\hline $\mathrm{FBP}$ & 655.4 & 587.6 & 605.2 & 614.1 \\
\hline Residue & 1.1 & 1.2 & 0.8 & 1.0 \\
\hline
\end{tabular}

* Yield in weight regarding the COMMERCIAL DIESEL FUEL fed into the fractionating unit.

\section{Profile of the 13-step steady state cycle}

Part 1 of the ISO 8178 standard and Appendix 4 of the ECE-R49 regulation specify the methods to measure and evaluate gaseous emissions and PM emissions coming from exhaust pipes of reciprocal internal combustion engines (RIC) under steady state conditions in a test cell. In order to carry out these evaluations, several combinations of feed and engine speed were used, which reflect the different operating conditions of diesel engines. These methods are applicable to the reciprocal internal combustion engines used in stationary equipment and mobile sources, and they have many aspects in common with the method of total dilution specified for engine certification of heavy-duty vehicles starting with 1985 models in the United States.

The purpose of this standard and regulation is to provide the characteristic profile of the emissions of an engine which, by using the appropriate weighting factors, can be used as an indicator of the emission levels of this engine in its different applications. The results of the emissions are expressed in grams per kilowatt-hour ( $\mathrm{gr} / \mathrm{kW}-\mathrm{hr}$ ) and represent the mass flow of contaminating emission per work-unit.

The profile of the 13-step steady state cycle is defined 
Table 4. Characterization of kerosene and diesel blends. Engine 2.

\begin{tabular}{|c|c|c|c|c|}
\hline TEST & Kerosene & $\begin{array}{c}\text { Diesel } 71 \% \\
\text { Kero } 29 \%\end{array}$ & $\begin{array}{c}\text { Diesel } 82 \% \\
\text { Kero 18\% }\end{array}$ & $\begin{array}{c}\text { Diesel } 89 \% \\
\text { Kero } 11 \%\end{array}$ \\
\hline API Gravity & 39.6 & 33.8 & 32.9 & 32.4 \\
\hline Density at $288.6 \mathrm{~K}\left(\mathrm{Kg} / \mathrm{m}^{3}\right)$ & 826.6 & 855.6 & 859.2 & 862.9 \\
\hline Sulfur (\% w) & 0.058 & 0.215 & 0.249 & 0.268 \\
\hline Viscosity at $313 \mathrm{~K}\left(\mathrm{~m}^{2} / \mathrm{s}\right)$ & - & $3.12 \mathrm{E}-06$ & $3.42 \mathrm{E}-06$ & 3.67E-06 \\
\hline Flash Point ( K) & - & 336.0 & 340.0 & 342.0 \\
\hline Cetane Index & - & 45.6 & 45.8 & 45.6 \\
\hline Distillation ( K) & D-86 & D-86 & D-86 & D-86 \\
\hline $\mathrm{IBP}$ & 451.4 & 443.2 & 462.0 & 455.8 \\
\hline 5\% Evaporated & 465.4 & 478.0 & 477.3 & 486.7 \\
\hline 10\% Evaporated & 469.8 & 489.4 & 485.4 & 499.0 \\
\hline $20 \%$ Evaporated & 477.5 & 503.1 & 496.5 & 517.6 \\
\hline $30 \%$ Evaporated & 483.5 & 516.3 & 512.0 & 533.0 \\
\hline 40\% Evaporated & 488.6 & 529.4 & 527.5 & 545.2 \\
\hline 50\% Evaporated & 493.7 & 541.5 & 540.0 & 556.5 \\
\hline $60 \%$ Evaporated & 499.0 & 555.3 & 551.8 & 568.2 \\
\hline 70\% Evaporated & 504.8 & 571.0 & 564.2 & 581.0 \\
\hline 80\% Evaporated & 512.0 & 588.9 & 578.9 & 595.8 \\
\hline 90\% Evaporated & 522.6 & 611.7 & 593.9 & 615.8 \\
\hline 95\% Evaporated & 536.9 & 630.3 & 615.3 & 631.3 \\
\hline FBP & 564.6 & 649.0 & 633.2 & 651.7 \\
\hline Residue & 1.3 & 1.0 & 0.8 & 0.6 \\
\hline
\end{tabular}

using the revolutions per minute (RPM) of the engine at maximum torque (intermediate speed) and maximum power (rated speed). On this basis, three ranges and 13 steps of evaluation are defined; the range of "intermediate speed" that has five steps with loads at $10 \%$, $25 \%, 50 \%, 75 \%$ and $100 \%$ maximum torque, the "rated speed" range that also has 5 steps with loads at $10 \%$, $25 \%, 50 \%, 75 \%$ and $100 \%$ maximum power and the range at ralenti with three steps - one at the beginning of the cycle, one between "intermediate speed" and "rated speed" and one at the end of the cycle. Each step has a duration of 360 seconds, with emission sampling periods defined in agreement with the weighting factors, which are characteristic of the conditions of each region or country.

\section{CHARACTERISTICS OF THE ENGINES EVALUATED}

Due to the need for carrying out evaluations conserving the characteristics of the fleet of public service vehicles in Colombian cities, we decided to select engines that represent the vehicles currently being assembled in Colombia, or those to be assembled in the near future, and engines that have been used to convert buses from gas to diesel fuel. The specifications of these engines are illustrated in Table No. 9. 
Table 5. Characterization of the disel fuel and its fractions. Engine 1.

\begin{tabular}{|c|c|c|c|c|}
\hline TEST & $\begin{array}{l}\text { Commercial } \\
\text { Diesel }\end{array}$ & $\begin{array}{c}\text { Diesel } \\
\text { FBP - } 593 \mathrm{~K}\end{array}$ & $\begin{array}{c}\text { Diesel } \\
\text { FBP - } 613 \mathrm{~K}\end{array}$ & $\begin{array}{c}\text { Diesel } \\
\text { FBP - } 633 \mathrm{~K}\end{array}$ \\
\hline API Gravity & 33.8 & 35.4 & 34.7 & 34.2 \\
\hline Density at $288.6 \mathrm{~K}\left(\mathrm{Kg} / \mathrm{m}^{3}\right)$ & 855.6 & 847.4 & 850.9 & 853.5 \\
\hline Sulfur $(\% w)$ & 0.213 & 0.157 & 0.179 & 0.201 \\
\hline Viscosity at $313 \mathrm{~K}\left(\mathrm{~m}^{2} / \mathrm{s}\right)$ & $3.2 \mathrm{E} 06$ & $2.49 \mathrm{E} 06$ & 2.5E 06 & 2.94E 08 \\
\hline Flash Point ( $K$ ) & 344 & 343 & 341 & 346 \\
\hline Cetane Index & 46.6 & 43.9 & 44.9 & 46.2 \\
\hline Yield \% w (D-2892) * & - & 78.4 & 87.6 & 94.2 \\
\hline Distillation ( $K$ ) & D-86 & D-86 & D-86 & D-86 \\
\hline $\mathrm{IBP}$ & 459.5 & 450.2 & 451.3 & 469.3 \\
\hline 5\% Evaporated & 486.3 & 476.2 & 480.0 & 483.8 \\
\hline 10\% Evaporated & 496.6 & 484.6 & 489.2 & 494.7 \\
\hline 20\% Evaporated & 514.5 & 499.7 & 506.5 & 511.9 \\
\hline $30 \%$ Evaporated & 527.9 & 511.4 & 519.2 & 525.8 \\
\hline $40 \%$ Evaporated & 538.8 & 521.0 & 529.0 & 536.0 \\
\hline $50 \%$ Evaporated & 548.1 & 528.6 & 537.1 & 544.8 \\
\hline $60 \%$ Evaporated & 558.5 & 535.6 & 544.9 & 553.7 \\
\hline 70\% Evaporated & 569.0 & 542.6 & 553.1 & 563.2 \\
\hline 80\% Evaporated & 582.1 & 550.4 & 562.4 & 574.1 \\
\hline $90 \%$ Evaporated & 600.3 & 560.1 & 573.3 & 587.4 \\
\hline 95\% Evaporated & 619.3 & 566.4 & 580.4 & 596.1 \\
\hline FBP & 642.5 & 577.4 & 590.6 & 606.0 \\
\hline Residue & 1.2 & 0.8 & 1.0 & 1.0 \\
\hline
\end{tabular}

* Yield in weight regarding the COMMERCIAL DIESEL FUEL fed into the fractionating unit.

\section{ANALYSIS OF THE RESULTS OF P.M. EMISSIONS}

The significant variable that affects PM emissions is not FBP itself, but density, aromatic (poly-aromatic) content and sulfur content. The reduction in value of these variables, for our case in particular, was achieved: reducing the final point, adding kerosene and obtaining diesel cuts with low sulfur contents at the refinery and the Pilot Plant.

The analysis was carried out focusing on three actions (reducing FBP, adding kerosene and reducing sulfur) and it should be kept in mind that in the cases analyzed, the effects on emissions are due to the modification of the three significant variables (FBP, density, sulfur) and in our case, it was not about weighting the effect of each variable separately. The interrelation between diesel properties makes it difficult to particularize the contribution of one specific property on emissions with certainty.

General tendencies show reductions in PM emissions when the three characteristics studied are reduced. Nevertheless, the effect varies from one engine to another depending on technology and working time, as 
Table 6. Characterization of kerosene and diesel blends. Engine 1.

\begin{tabular}{|c|c|c|c|c|}
\hline TEST & Kerosene & $\begin{array}{c}\text { Diesel } 71 \% \\
\text { Kero } 29 \%\end{array}$ & $\begin{array}{c}\text { Diesel 84\% } \\
\text { Kero 6\% }\end{array}$ & $\begin{array}{c}\text { Diesel } 93 \% \\
\text { Kero } 7 \%\end{array}$ \\
\hline API Gravity & 39.6 & 35.2 & 34.9 & 34.3 \\
\hline Density at $288.6 \mathrm{~K}\left(\mathrm{Kg} / \mathrm{m}^{3}\right)$ & 826.6 & 848.4 & 850.4 & 853.0 \\
\hline Sulfur (\% w) & 0.058 & 0.18 & 0.197 & 0.216 \\
\hline Viscosity at $313 \mathrm{~K}\left(\mathrm{~m}^{2} / \mathrm{s}\right)$ & - & 2.60E-06 & 2.73E-06 & 2.87E-06 \\
\hline Flash Point ( K) & - & 338.0 & 338.0 & 334.0 \\
\hline Cetane Index & - & 45.6 & 45.7 & 45.4 \\
\hline Distillation ( K) & $\mathrm{D}-86$ & D-86 & D-86 & D-86 \\
\hline $\mathrm{IBP}$ & 451.4 & 447.4 & 451.4 & 444.2 \\
\hline 5\% Evaporated & 465.4 & 475.6 & 477.3 & 477.3 \\
\hline 10\% Evaporated & 469.8 & 484.5 & 485.7 & 485.7 \\
\hline $20 \%$ Evaporated & 477.5 & 497.7 & 498.9 & 498.9 \\
\hline $30 \%$ Evaporated & 483.5 & 509.4 & 510.7 & 511.6 \\
\hline 40\% Evaporated & 488.6 & 520.3 & 522.1 & 523.7 \\
\hline 50\% Evaporated & 493.7 & 530.6 & 533.5 & 536.1 \\
\hline $60 \%$ Evaporated & 499.0 & 541.8 & 546.0 & 549.5 \\
\hline 70\% Evaporated & 504.8 & 555.0 & 560.1 & 565.4 \\
\hline $80 \%$ Evaporated & 512.0 & 571.0 & 577.9 & 585.0 \\
\hline 90\% Evaporated & 522.6 & 592.3 & 601.0 & 610.2 \\
\hline 95\% Evaporated & 536.9 & 609.8 & 620.5 & 631.2 \\
\hline FBP & 564.6 & 634.5 & 640.7 & 645.8 \\
\hline Residue & 1.3 & 1.2 & 1.2 & 1.0 \\
\hline
\end{tabular}

can be seen in Figures 1 through 4. In general, the reduction of FBP, as illustrated in Tables 3, 5 and 7 brings reductions in density and sulfur content, generates reductions of up to $22 \%$ in PM emissions. The reduction in sulfur content generates reductions of up to $27 \%$, as illustrated in Table 12 and Figures 5 and 6, although in the case of the fuel obtained from the Refinery by operational modification, some other properties were affected. The effect of density reduced by adding kerosene on emissions is less significant than that of the other alternatives.

Nevertheless, as illustrated in Table 10 and Figures 1 through 4, for the technology of traditional engines with high levels of use and emissions, there are no benefits for improving fuel quality. If we observe the levels of emissions and compare them with European standards, we see that with low sulfur fuels in Euro II technology engines, emissions are very close to the values specified, as shown in Figure 5.

To complement this general analysis of the tendencies obtained by modifying the parameters of fuel quality, we will analyze each engine separately. Although it has been found that, by interaction between the different parameters of diesel quality, the modification of any of these parameters generates changes in the others, we will refer to the basic parameter that was to be modified, as an option in the improvement of fuel quality, and not as a modification of the property itself. 
Table 7. Characterization of diesel fuel and its fractions. Engines 3 and 4.

\begin{tabular}{|c|c|c|c|c|}
\hline TEST & $\begin{array}{c}\text { Commercial } \\
\text { Diesel }\end{array}$ & $\begin{array}{c}\text { Diesel } \\
\text { FBP - } 593 \mathrm{~K}\end{array}$ & $\begin{array}{c}\text { Diesel } \\
\text { FBP }-613 \mathrm{~K}\end{array}$ & $\begin{array}{c}\text { Diesel } \\
\text { FBP - } 633 \mathrm{~K}\end{array}$ \\
\hline AP| Gravity & 32 & 33.3 & 32.6 & 32.3 \\
\hline Density at $288.6 \mathrm{~K}\left(\mathrm{Kg} / \mathrm{m}^{3}\right)$ & 865.5 & 858.7 & 862.4 & 863.9 \\
\hline Sulfur $(\% w)$ & 0.259 & 0.191 & 0.215 & 0.242 \\
\hline Viscosity at $313 \mathrm{~K}\left(\mathrm{~m}^{2} / \mathrm{s}\right)$ & $3.89 E 06$ & 2.96E 06 & $3.34 \mathrm{E} 06$ & 3.65E 06 \\
\hline Flash Point ( K) & 354.0 & 352.0 & 361.0 & 358.0 \\
\hline Cetane Index & 47.1 & 44.6 & 45.4 & 46.1 \\
\hline Yield \% w (D-2892)* & - & 74.16 & 85.89 & 94.42 \\
\hline Distillation ( $K$ ) & D-86 & D-86 & D-86 & D-86 \\
\hline $\mathrm{IBP}$ & 485.1 & 475.8 & 479.7 & 484.2 \\
\hline 5\% Evaporated & 5114 & 502.9 & 508.2 & 508.7 \\
\hline $10 \%$ Evaporated & 5230 & 512.3 & 517.7 & 519.1 \\
\hline $20 \%$ Evaporated & 534.3 & 523.9 & 529.6 & 532.1 \\
\hline $30 \%$ Evaporated & 544.1 & 531.7 & 538.0 & 541.0 \\
\hline 40\% Evaporated & 551.6 & 537.8 & 544.7 & 548.3 \\
\hline $50 \%$ Evaporated & 5599 & 543.2 & 550.8 & 555.2 \\
\hline $60 \%$ Evaporated & 568.2 & 548.7 & 557.4 & 562.7 \\
\hline 70\% Evaporated & 578.1 & 554.3 & 564.4 & 571.2 \\
\hline 80\% Evaporated & 589.5 & 561.0 & 572.3 & 580.7 \\
\hline $90 \%$ Evaporated & 6051 & 569.0 & 581.9 & 592.4 \\
\hline 95\% Evaporated & 6163 & 574.2 & 588.0 & 600.6 \\
\hline FBP & 6325 & 582.4 & 596.4 & 609.1 \\
\hline Residue & 0.6 & 1.1 & 1.0 & 1.2 \\
\hline
\end{tabular}

* Yield in weight regarding the COMMERCIAL DIESEL FUEL fed into the fractionating unit.

\section{Results Engine 1}

The index of PM emissions determined for Engine 1 is $0.75 \mathrm{~g} / \mathrm{kW}-\mathrm{h}$. There was no reduction in the level of emissions for any of the options evaluated to improve commercial diesel fuel quality. Table 10 contains a summary of the results.

The high level of emissions are in accordance with the characteristics of Engine 1; engine with many hours of use, with a design philosophy that does not go with the modern technology of low emissions (Euro I or later). Engine technology and mechanical conditions explain why there were no improvements in emissions when fuel quality was changed.

\section{Results Engine 2.}

The results of PM emissions for whole diesel evaluated in Engine $2(0.214 \mathrm{~g} / \mathrm{kWh})$, are below the Euro I standard $(0,36 \mathrm{~g} / \mathrm{kWh})$ for engines with power greater than $85 \mathrm{~kW}$. Important reductions in PM emissions take place when the Final Boiling Point of the diesel is reduced, reaching the best results (reductions of $22 \%$ ) with the FBP-613K $\left(340{ }^{\circ} \mathrm{C}\right)$ cut. The changes in density (blends with Kero) are less significant. Table11 summarizes the results for each of the fuels tested. 
Table 8. Characterization of kerosene and diesel blends. Engine 1 and 4 .

\begin{tabular}{|c|c|c|c|c|}
\hline TEST & Kerosene & $\begin{array}{l}\text { Diesel } 81 \% \\
\text { Kero } 19 \%\end{array}$ & $\begin{array}{l}\text { Diesel 92\% } \\
\text { Kero 8\% }\end{array}$ & $\begin{array}{c}\text { Diesel 95\% } \\
\text { Kero 5\% }\end{array}$ \\
\hline API Gravity & 39.6 & 33.4 & 32.5 & 32.2 \\
\hline Density at $288.6 \mathrm{~K}\left(\mathrm{Kg} / \mathrm{m}^{3}\right)$ & 826.6 & 857.7 & 862.4 & 863.9 \\
\hline Sulfur (\% w) & 0.05 & 0.215 & 0.234 & 0.245 \\
\hline Viscosity at $313 \mathrm{~K}\left(\mathrm{~m}^{2} / \mathrm{s}\right)$ & - & 3.15E-06 & 3.57E-06 & 3.72E-06 \\
\hline Flash Point ( K) & - & 340.0 & 347.0 & 348.0 \\
\hline Cetane Index & - & 45.6 & 46.1 & 46.3 \\
\hline Distillation ( K) & D-86 & D-86 & D-86 & D-86 \\
\hline IBP & 451.4 & 464.9 & 472.9 & 478.7 \\
\hline 5\% Evaporated & 465.4 & 489.6 & 499.0 & 504.6 \\
\hline 10\% Evaporated & 469.8 & 498.0 & 511.1 & 514.9 \\
\hline 20\% Evaporated & 477.5 & 513.1 & 524.3 & 529.4 \\
\hline 30\% Evaporated & 483.5 & 524.6 & 535.1 & 539.9 \\
\hline 40\% Evaporated & 488.6 & 535.2 & 544.4 & 548.5 \\
\hline $50 \%$ Evaporated & 493.7 & 545.7 & 553.5 & 556.5 \\
\hline $60 \%$ Evaporated & 499.0 & 556.4 & 562.8 & 565.5 \\
\hline 70\% Evaporated & 504.8 & 568.5 & 573.3 & 575.8 \\
\hline 80\% Evaporated & 512.0 & 582.4 & 585.3 & 341.0 \\
\hline $90 \%$ Evaporated & 522.6 & 599.6 & 601.2 & 603.0 \\
\hline 95\% Evaporated & 536.9 & 612.9 & 613.0 & 614.9 \\
\hline FBP & 564.6 & 625.8 & 626.6 & 627.9 \\
\hline Residue & 1.3 & 1.0 & 1.2 & 1.3 \\
\hline
\end{tabular}

\section{Effect of reducing FBP.}

There are reductions in PM emissions when Final Boiling Point (FBP) is lowered, reaching the greatest reduction $(22 \%)$ with the $613 \mathrm{~K}\left(340{ }^{\circ} \mathrm{C}\right) \mathrm{FBP}$ fuel. Nevertheless, the effect of reduction is slightly lower for the fuel with a FBP of $593 \mathrm{~K}\left(320^{\circ} \mathrm{C}\right)$.

\section{Effect of adding kerosene.}

For the engine analyzed, the addition of kerosene (variation in density) is not a determining parameter to improve emissions. There is a slight reduction in emissions when density is reduced maintaining a constant FBP. The effect of density on the reduction of PM emissions is very low compared to the results obtained by varying FBP.

\section{Effect of reducing sulfur content.}

Table 12 illustrates the behavior of PM emissions regarding fuel sulfur content. The diesel with the highest level of emissions is also that with the greatest sulfur content (3400 ppm). Emissions tend to decrease as sulfur content is reduced Figures 5 and 6. Nevertheless, the fuel with the best behavior as far as emissions is the blend denominated U-150+Mez GCB which has a sulfur content of $1000 \mathrm{ppm}$, although it has the highest cetane index (55.4) and the lowest density (838.8). This result reaffirms the difficulty of particularizing the effect of one specific variable on emissions, more so when it 
Table 9. Technical specifications of the engines evaluated.

\begin{tabular}{|c|c|c|c|c|}
\hline & Engine 1 & Engine 2 & Engine 3 & Engine 4 \\
\hline No. of cylinders & 6 in-line & 6 in-line & 6 in-line & 4 in-line \\
\hline Displacement (m3) & 6.6 & 7.1 & 6.0 & 3.5 \\
\hline Turbocharged & Yes & Yes & Yes & Yes \\
\hline Intercooler. & Yes & Yes & No & Yes \\
\hline Compression ratio & $18: 1$ & $17.5: 1$ & $18.5: 1$ & $18: 1$ \\
\hline Feeding system & Direct Injection & Direct Injection & Direct Injection & Direct Injection \\
\hline Maximum Power & 138 kW@ 2600 RPM. & 151 kW@ 2800 RPM. & 119 kW@2500 RPM. & 85 kW @ 3200 RPM. \\
\hline Maximum torque & 706.0 N-m@1560RPM & 598.0 N-m @ 1700 RPM. & 550.0 N-m@2250 RPM. & 311.8 N-m@2000 RPM. \\
\hline Technology & * & EURO ॥ & * & * \\
\hline
\end{tabular}

* Engine without technology emissions specification.

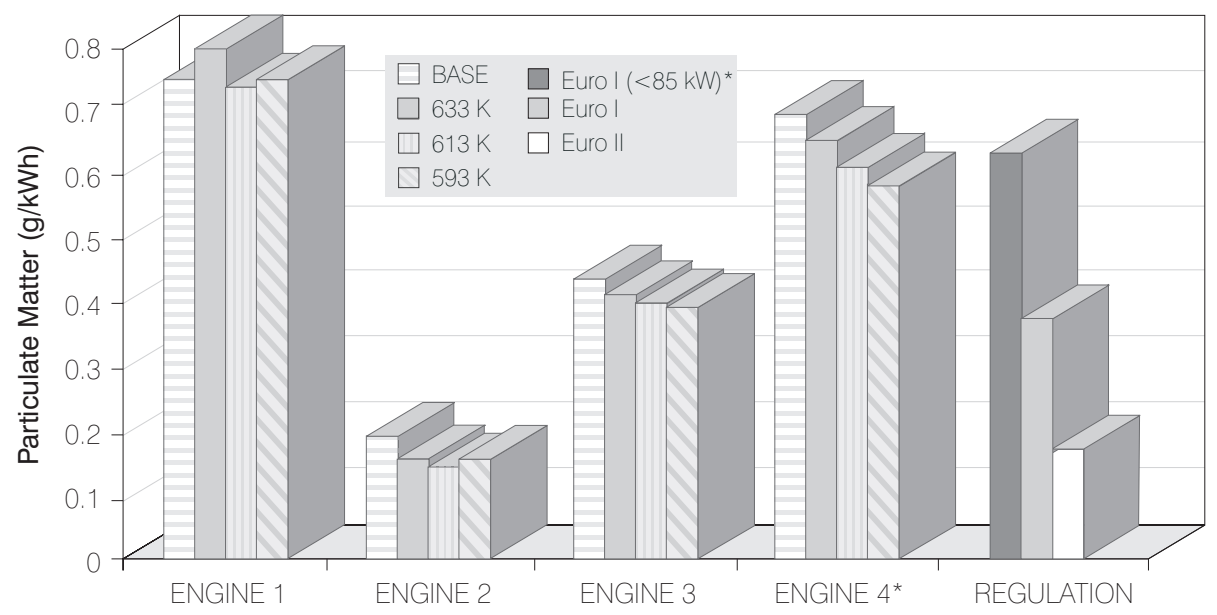

Figure 1. Particulate Matter Emissions vs FBP

is difficult to control the interaction between properties at the operational level.

PM emissions for the engine analyzed with the low sulfur fuels are close to the Euro II specification ( 0.15 $\mathrm{g} / \mathrm{kWh}$ ), parameter which matches the U-150+Mez GCB blend.

\section{Results Engine 3.}

PM emissions with whole diesel fuel are above the Euro I regulation $(0.36 \mathrm{~g} / \mathrm{kWh}$ for heavy-duty engines, $>85 \mathrm{~kW}$ ), with the U-2000 + Mez GCB blend. There is a marked tendency toward the reduction of PM emissions with the FBP and Density variables. Table 13 shows a summary of the results.

\section{Effect of reducing FBP.}

There are reductions in PM emissions as FBP is reduced, reaching the greatest value $(13 \%)$ with the fuel that has a FBP of $593 \mathrm{~K}\left(320^{\circ} \mathrm{C}\right)$. The $633 \mathrm{~K}\left(360^{\circ} \mathrm{C}\right)$ cut does not show significant reduction compared to commercial diesel, while in terms of PM emission, there is no benefit when shifting from $613 \mathrm{~K}\left(340^{\circ} \mathrm{C}\right)$ to $593 \mathrm{~K}$ $\left(320^{\circ} \mathrm{C}\right)$.

\section{Effect of adding kerosene.}

The best results of the effect of density are obtained 

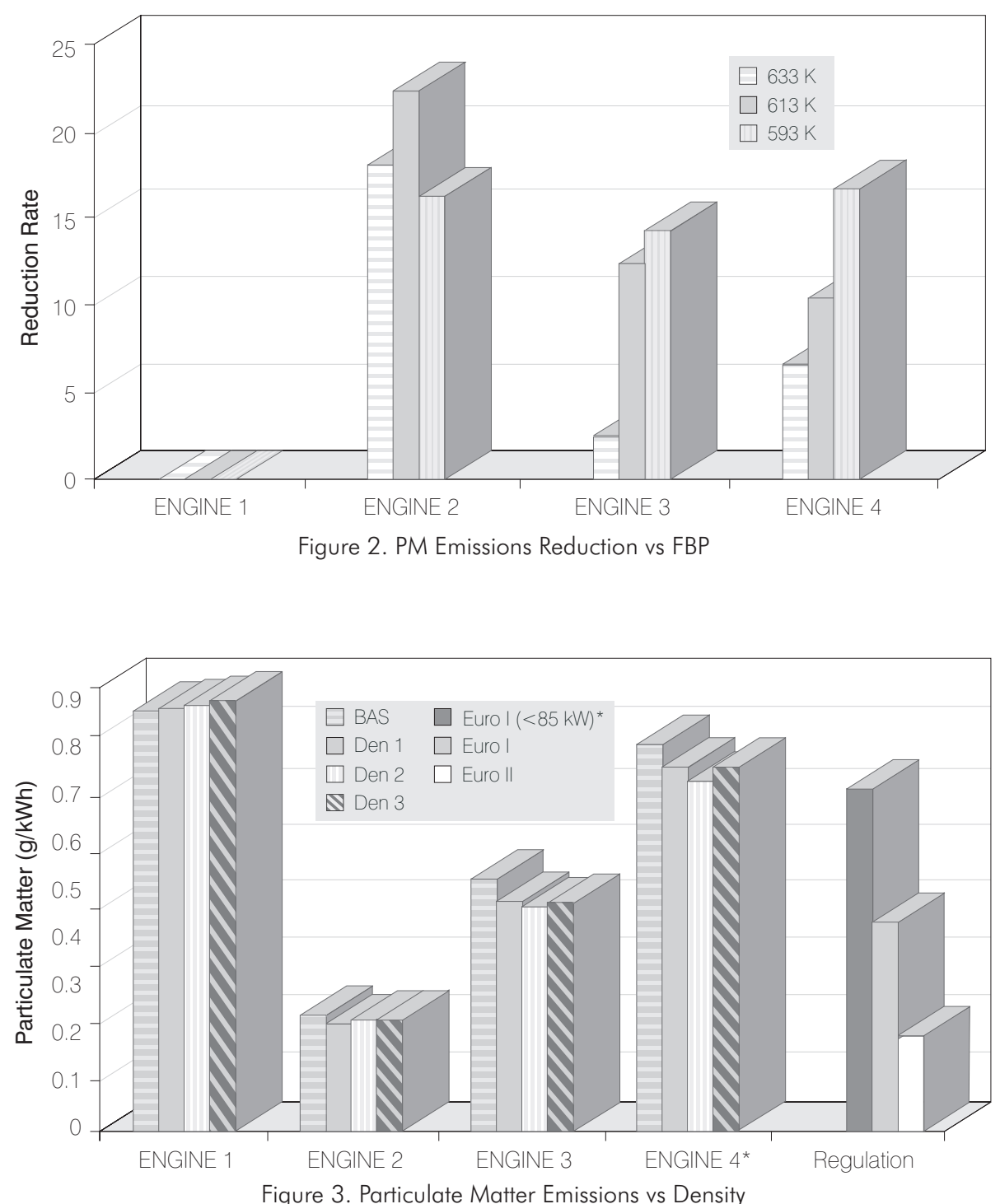

Figure 3. Particulate Matter Emissions vs Density

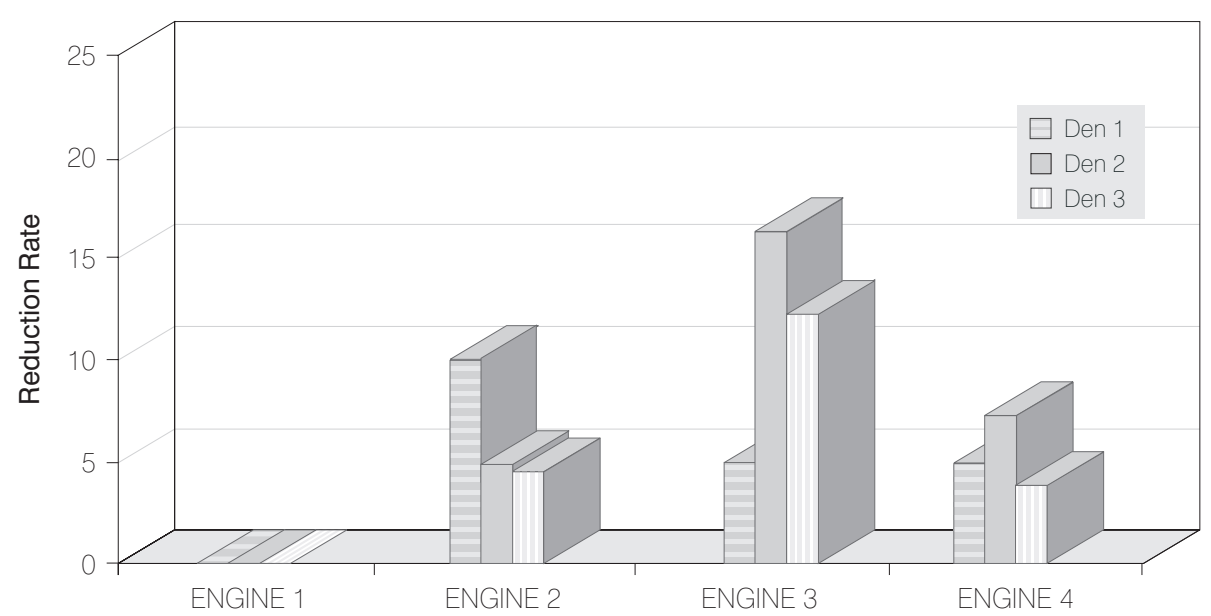

Figure 4. PM Emissions Reduction vs Density 


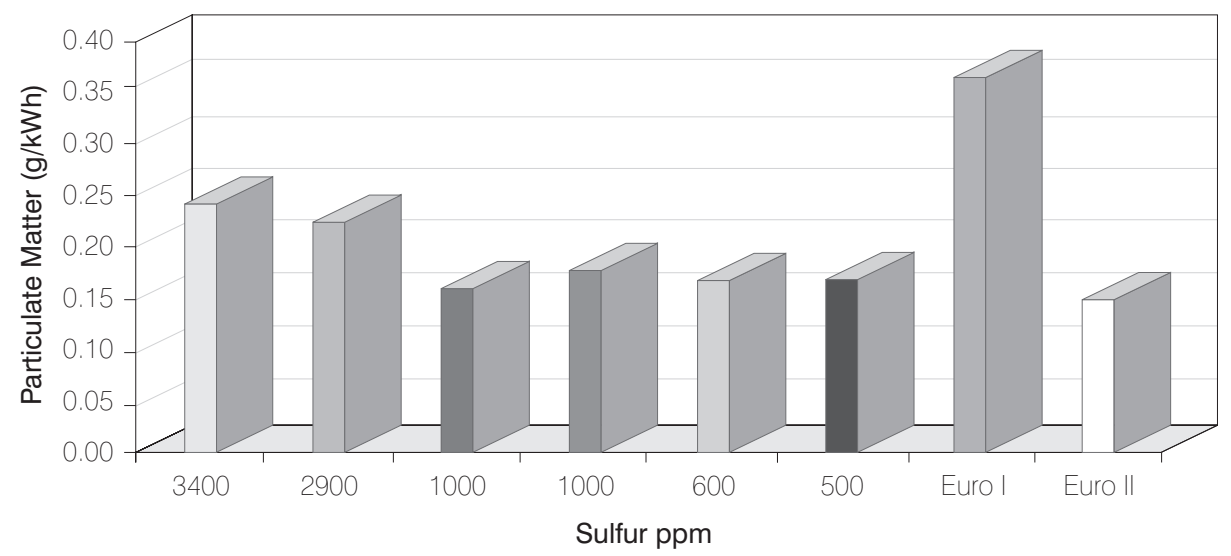

Figure 5. PM Emissions Engine 2

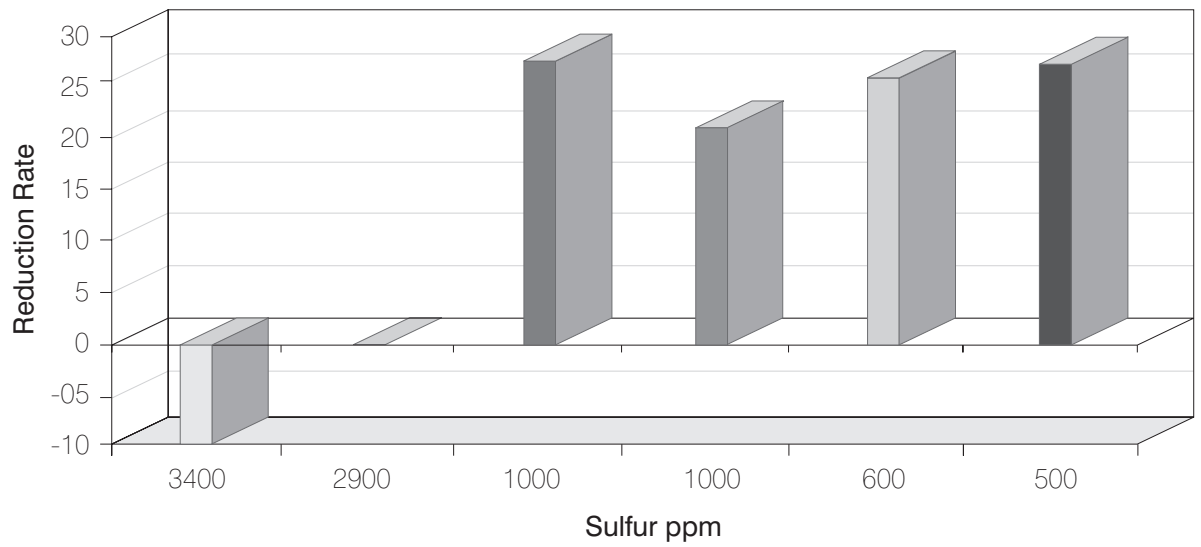

Figure 6. PM Emissions Reduction Engine 2

Table 10. PM Emissions (g/kWh), Engine 1.

\begin{tabular}{|c|c|c|c|c|c|c|c|c|}
\hline & \multicolumn{4}{|c|}{ CUTS } & \multicolumn{3}{|c|}{ BLENDS WITH KERO } & \multirow{2}{*}{$\begin{array}{l}\text { HDT 1* } \\
\text { Pilot PI. }\end{array}$} \\
\hline & Whole & FBP-633 & FBP-613 & FBP-593 & $93 / 7$ & $84 / 16$ & $71 / 29$ & \\
\hline Density & 855.6 & 853.5 & 850.9 & 847.4 & 853.0 & 850.4 & 848.4 & 857.7 \\
\hline$\%$ Sulfur & 0.213 & 0.201 & 0.179 & 0.157 & 0.216 & 0.197 & 0.180 & 0.030 \\
\hline PM Test-1 & 0.7464 & 0.758 & 0.752 & 0.762 & 0.751 & 0.776 & 0.774 & 0.719 \\
\hline PM Test-2 & 0.7400 & 0.793 & 0.725 & 0.738 & 0.755 & 0.738 & 0.738 & 0.746 \\
\hline Average & 0.752 & 0.776 & 0.738 & 0.749 & 0.753 & 0.757 & 0.756 & 0.733 \\
\hline Std. Devi. & 0.017 & 0.025 & 0.019 & 0.018 & 0.003 & 0.027 & 0.025 & 0.019 \\
\hline Var. Coef. & 2.257 & 3.191 & 2.585 & 2.445 & $0.376-$ & 3.550 & 3.367 & 2.606 \\
\hline \%Reduc. ** & 0.0 & -3.13 & 1.8 & 0.4 & 0.13 & -0.66 & -0.53 & 2.59 \\
\hline
\end{tabular}

* Low sulfur diesel obtained through hydrotreatment in the Pilot Plant from whole diesel.

** The reduction rate is calculated in comparison with commercial diesel (whole). 
Table 11. PM Emissions (g/kWh), Engine 2.

\begin{tabular}{|c|c|c|c|c|c|c|c|}
\hline & \multicolumn{9}{c|}{ CUTS } & \multicolumn{3}{c|}{ BLENDS WITH KERO } \\
\cline { 2 - 9 } & Whole & FBP-633 & FBP-613 & FBP-593 & $89 / 11$ & $82 / 18$ & $71 / 29$ \\
\hline Density & 866.6 & 862.9 & 859.2 & 855.1 & 862.9 & 859.2 & 855.6 \\
\hline \% Sulfur & 0.292 & 0.239 & 0.213 & 0.177 & 0.268 & 0.249 & 0.215 \\
\hline PM & 0.212 & 0.179 & 0.170 & 0.175 & 0.198 & 0.204 & 0.205 \\
\hline PM & 0.216 & 0.172 & 0.164 & 0.183 & 0.190 & - & - \\
\hline Average & 0.214 & 0.176 & 0.167 & 0.179 & 0.194 & 0.204 & 0.205 \\
\hline Std. Devi. & 0.002 & 0.004 & 0.003 & 0.004 & 0.004 & - & - \\
\hline Var. Coef. & 0.935 & 1.994 & 1.796 & 2.235 & 2.065 & - & - \\
\hline \%Reduc. ${ }^{*}$ & 0.0 & 17.99 & 21.96 & 16.36 & 9.35 & 4.67 & 4.21 \\
\hline
\end{tabular}

* The reduction rate is calculated in comparison with commercial diesel (whole).

Table 12. PM Emissions (g/kWh), Engine 2.

\begin{tabular}{|c|c|c|c|c|c|c|}
\hline \multirow[b]{2}{*}{ Samples } & \multicolumn{5}{|c|}{ VARIATION IN SULFUR CONTENT } & \multirow[b]{2}{*}{$\begin{array}{l}\text { HDT } 2^{\star *} \\
\text { Pilot PI.. }\end{array}$} \\
\hline & Whole & Mez GCB & $\begin{array}{c}\mathrm{U}-2000+\mathrm{Mez} \\
\text { GCB }\end{array}$ & $\begin{array}{c}U-150+M e z \\
\text { GCB }\end{array}$ & U-2000 & \\
\hline Sulfur & 2900 PPM & 3400 PPM & 1000 PPM & 1000 PPM & 600 PPM & 500 PPM \\
\hline Density & 866.6 & 879.5 & 853.5 & 838.5 & 848.9 & 858.2 \\
\hline PM & 0.212 & 0.227 & 0.171 & 0.156 & 0.162 & 0.158 \\
\hline PM & 0.216 & 0.239 & - & - & 0.165 & 0.161 \\
\hline Average & 0.214 & 0.233 & 0.171 & 0.156 & 0.164 & 0.160 \\
\hline Std. Devi. & 0.004 & 0.006 & - & - & 0.001 & 0.001 \\
\hline Var. Coef. & 1.994 & 2.575 & - & - & 0.917 & 0.940 \\
\hline$\%$ Redu. * & 0.0 & -8.88 & 20.1 & 27.1 & 23.6 & 25.47 \\
\hline
\end{tabular}

* The reduction rate is calculated in comparison with commercial diesel (whole).

** Low sulfur diesel obtained through hydrotreatment (HDT) at the Pilot plant

in Engine 3. There are reductions of up to $15 \%$ in emissions when lowering density by adding kerosene. Nevertheless, the reduction rate drops for the blend with the greatest kerosene content (19\%). This result coincides with the unstable operation of the engine with this fuel.

\section{Effect of reducing sulfur content.}

A sample with a sulfur content of $1000 \mathrm{ppm}(\mathrm{U}$ -
$2000+$ Mezc GCB) was evaluated, prepared with cuts obtained at the Barrancabermeja Refinery. Reductions in PM emissions of about 22\% were reached, compared to commercial diesel (2600 ppm). Emissions with this fuel are $0.351 \mathrm{~g} / \mathrm{kWh}$, complying with the Euro I standard.

\section{Results Engine 4.}

The cut with a FBP of $613 \mathrm{~K}\left(340^{\circ} \mathrm{C}\right)$, option which 
Table 13. PM Emissions ( $\mathrm{g} / \mathrm{kWh})$, Engine 3.

\begin{tabular}{|c|c|c|c|c|c|c|c|c|}
\hline & \multicolumn{4}{|c|}{ CUTS } & \multicolumn{3}{|c|}{ BLENDS WITH KERO } & \multirow{2}{*}{$\begin{array}{l}\text { U-2000+ } \\
\text { Mez GCB }\end{array}$} \\
\hline & Whole & FBP-633 & FBP-613 & FBP-593 & $95 / 5$ & $92 / 8$ & $81 / 19$ & \\
\hline Density & 865.5 & 863.9 & 862.4 & 858.7 & 863.9 & 862.9 & 858.2 & 853.5 \\
\hline$\%$ Sulfur & 0.259 & 0.242 & 0.215 & 0.191 & 0.245 & 0.234 & 0.215 & 0.100 \\
\hline PM & 0.465 & 0.451 & 0.384 & 0.382 & 0.404 & 0.373 & 0.409 & 0.351 \\
\hline PM & 0.439 & 0.429 & 0.410 & 0.401 & 0.427 & 0.393 & 0.393 & \\
\hline Average & 0.452 & 0.440 & 0.397 & 0.392 & 0.416 & 0.383 & 0.401 & 0.351 \\
\hline Std. Devi. & 0.013 & 0.011 & 0.013 & 0.010 & 0.012 & 0.010 & 0.011 & - \\
\hline Var. Coef. & 2.86 & 2.5 & 3.275 & 2.427 & 2.768 & 2.611 & 1.995 & \\
\hline \% Redu. * & 0.0 & 2.65 & 12.17 & 13.38 & 8.08 & 15.27 & 11.28 & 22.34 \\
\hline
\end{tabular}

* The reduction rate is calculated in comparison with commercial diesel (whole).

Table 14. PM Emissions (g/kWh), Engine 4.

\begin{tabular}{|c|c|c|c|c|c|c|c|c|}
\hline & \multicolumn{4}{|c|}{ CUTS } & \multicolumn{3}{|c|}{ BLENDS WITH KERO } & \multirow{2}{*}{$\begin{array}{l}\text { HDT 1* } \\
\text { Pilot PI. }\end{array}$} \\
\hline & Whole & FBP-633 & FBP-613 & FBP-593 & $95 / 5$ & $92 / 8$ & $81 / 19$ & \\
\hline Density & 865.5 & 863.9 & 862.4 & 858.7 & 863.9 & 862.9 & 858.2 & 857.7 \\
\hline$\%$ Sulfur & 0.259 & 0.242 & 0.215 & 0.191 & 0.245 & 0.234 & 0.215 & 0.030 \\
\hline PM Test-1 & 0.680 & 0.629 & 0.609 & 0.573 & 0.636 & 0.637 & 0.660 & 0.647 \\
\hline PM Test-2 & 0.682 & 0.649 & 0.614 & 0.570 & 0.669 & & - & 0.617 \\
\hline Average & 0.681 & 0.639 & 0.612 & 0.572 & 0.653 & 0.637 & 0.660 & 0.632 \\
\hline Std. Devi. & 0.001 & 0.014 & 0.004 & 0.002 & 0.023 & & - & 0.021 \\
\hline Var. Coef. & 0.208 & 2.213 & 0.578 & 0.371 & 3.576 & - & - & 3.357 \\
\hline \%Reduc. ** & 0.0 & 6.17 & 10.21 & 16.08 & 4.19 & 6.46 & 3.08 & 7.20 \\
\hline
\end{tabular}

* Low sulfur diesel is obtained through hydrotreatment at the Pilot Plant.

** The reduction rate is calculated in comparison with commercial diesel (whole).

is economically more viable from the volumetric loss viewpoint, complies with the Euro I parameter $(0.612 \mathrm{~g} / \mathrm{kWh})$ for engines with power $<85 \mathrm{~kW}$. The results of PM emission for commercial diesel $(0.681 \mathrm{~g} / \mathrm{kWh})$ are above this standard. The best results are obtained with changes in FBP. The effects of density and sulfur content are less important. Table 14 contains a summary of the results.

\section{Effect of reducing FBP.}

The general trend continues where there is a reduction in PM emissions as FBP is lowered, reaching the great- est reduction $(16 \%)$ with the $593 \mathrm{~K}\left(320^{\circ} \mathrm{C}\right) \mathrm{FBP}$ fuel.

\section{Effect of adding kerosene.}

The effect of density on the reduction of PM emission is very little, compared to the results obtained upon varying FBP. Despite the variation in fuel properties with $19 \%$ kerosene, engine operation was normal for the three fuels evaluated.

\section{Effect of reducing sulfur content.}

Diesel with a sulfur content of 300 ppm was obtained 
by using a commercial diesel (2600 ppm sulfur) through hydrotreatment in the pilot plant. Reductions of about $7 \%$ are reached with this fuel, very low compared to those obtained with the variation of FBP. This factor should be considered in the reformulation and specification of diesel characteristics.

\section{CONCLUSiOnS}

- It is observed that indeed the emissions from diesel engines can be reduced by decreasing FBP or sulfur content in commercial diesel fuel. This tendency has a threshold because of engine technology, reaching a high of $27 \%$. Nevertheless, when comparing emissions among engine technologies for similar fuels, there are differences of up to $70 \%$.

- The high levels of emissions and the lack of change in the levels of emission in Engine 1 (traditional technology with many hours of use) with the fuels evaluated, compared to the differences in emissions and reduction rates in the other engines evaluated, make evident the importance of considering fuel quality along with mechanical conditions and engine technology when dealing with aspects related to the reduction of emissions.

- The lowest level of emissions, close to Euro II specification $(0.15 \mathrm{~g} / \mathrm{kWh})$, are obtained with Engine 2 (Euro II Technology), where the diesel with the highest Cetane Index (55.4), lowest density (838.8) and a sulfur content of $1000 \mathrm{ppm}$ is the fuel with the best performance. Upon comparing these emissions with those of the commercial diesel fuel $(2900 \mathrm{ppm}$ sulfur) reductions of about $27 \%$ are reached. The diesel with 500 ppm sulfur (HDT 2) is next in order as far as reduction of PM emission, followed by the diesel with $1000 \mathrm{ppm}(\mathrm{U}-2000)$ and the cut with the FBP of $613 \mathrm{~K}\left(340^{\circ} \mathrm{C}\right)$, with reductions of about $24 \%$.

- As a general approximation, it is observed that from the reduction in PM emissions viewpoint, the FBP variable is that of greatest incidence. In all of the engines evaluated, except for Engine 1 due to its special characteristics, there is a tendency to obtain important reductions in PM emissions when FBP is lower. For the particular case of Engine 2, PM emissions can go from $0.214 \mathrm{~g} / \mathrm{kWh}$ to $0.167 \mathrm{~g} / \mathrm{kWh}$ (reduction of $22 \%$ ), when the diesel's FBP is lowered to $613 \mathrm{~K}\left(340^{\circ} \mathrm{C}\right)$. The influence of density on $\mathrm{PM}$ emissions is less significant.

- From the results, it would seem less favorable from the environmental viewpoint to reduce FBP to $613 \mathrm{~K}$ $\left(340{ }^{\circ} \mathrm{C}\right)(\mathrm{TBP})$, variable to be considered to decrease the effect of diesel emissions on the environment. It is possible, in our particular conditions, for this option to be more viable than reducing sulfur content. Nevertheless, this study must be complemented with evaluations of air quality in cities and technicaleconomical feasibility studies of impact in the refinery.

- Of all the blends evaluated, the one known as U$2000+$ Mez GCB (1000 ppm sulfur) comes closest to the characteristics of the fuel that will be distributed in Bogota-Colombia, starting in the year 2000. Reductions of about $22 \%$ in PM emissions are reached with this blend in Engine 3 (engine not specified under emissions standards) and $20 \%$ in Engine 2 (engine with Euro II technology).

\section{REFERENCES}

Asaumi, Yasuo et. al. "Effects of Fuel Properties on Diesel Exhaust Emissions Characteristics". SAE 922214.

Opris, Cornelius et.al. "The Effects of Fuel Sulfur Concentration on Regulated and Unregulated Heavy-duty Diesel Emissions". SAE 930730.

Owen, K., Trevor, C., 1990. Automotive Fuels Handbook. SAE Publications. 